\title{
STRATEGI PEMBELAJARAN INOVATIF PENDIDIKAN AGAMA ISLAM DENGAN MEDIA POWERPOINT DALAM MENINGKATKAN MUTU PENDIDIKAN DI SDIT MUHAMMADIYAH SINAR FAJAR CAWAS DAN SD MUHAMMADIYAH PK BAYAT
}

\author{
Sigit Trihariyanto ${ }^{1}$, Eko Supriyanto ${ }^{2}$, Muthoifin $^{3}$, Zahrotul Uyun $^{4}$ \\ 1,2,3 Magister Penidikan Agama Islam Sekolah Pascasarjana \\ Universitas Muhammadiyah Surakarta \\ ${ }^{4}$ Fakultas Psikologi Universitas Muhammadiyah Surakarta \\ E-Mail: sigit3hariyanto@yahoo.co.id, es113@ums.ac.id,mut122@ums.ac.id, \\ zu276@ums.ac.id
}

\begin{abstract}
This research was conducted with the aim of uncovering, analyzing and explaining learning strategies and utilizing PowerPoint media implemented by Islamic religious education teachers in delivering learning materials in the Integrated Islamic Elementary School of Muhammadiyah Sinar Fajar Cawas and the Special Program Elementary School of Muhammadiyah Bayat. This type of research is field research using a qualitative descriptive approach. The data sources and instruments used in this research are observation, interview and documentation study. Based on the research that has been done, the results show that the Integrated Islamic Elementary School of Muhammadiyah Sinar Fajar Cawas and the Special Program Elementary School of Muhammadiyah Bayat have implemented the 2013 curriculum. So that teachers have a very important role in education. Among the teacher roles shown in the two schools were the teacher as a planner, manager, implementer, and evaluator. Also, the teacher plays the role of transferring knowledge, fostering noble morals, mediators and facilitators. In the application of Islamic religious education learning strategies with PowerPoint media in the two schools, they can provide motivation and increase student enthusiasm for learning and learning achievements. In utilizing the strategy, it can make the learning process more attractive, effective, efficient and can help in conditioning students in the learning process and increase confidence for Islamic religious education teachers. As for material delivered using this strategy, it is easier to understand and more practical file storage. Supporting factors in implementing Islamic religious education learning strategies with PowerPoint media in Integrated Islamic Elementary School of Muhammadiyah Sinar Fajar Cawas and Special Program Elementary School of Muhammadiyah Bayat is the ability of teachers to operate computers, the availability of media resources, computer-based facilities, and infrastructure in schools, support from the head school, and the conducive condition of the school environment and the culture of mutual help to help those who are built are quite strong. As for the inhibiting factor is the lack of familiarity of teachers in using PowerPoint media in the learning process, the preparation time is still limited, and the number of computer-based facilities and infrastructure is still limited as well.
\end{abstract}

Keywords: learning strategies; media; powerpoint.

Abstrak: Penelitian ini dilaksanakan dengan tujuan untuk mengungkap, menganalisis dan menjelaskan strategi pembelajaran dan pemanfaatan media powerpoint yang diterapkan guru pendidikan agama Islam dalam menyampaikan materi pembelajaran di Sekolah Dasar Islam Terpadu Muhammadiyah Sinar Fajar Cawas dan Sekolah Dasar Muhammadiyah 
Program Khusus Bayat. Jenis Penelitian ini adalah penelitian lapangan (field research) dengan menggunakan pendekatan deskriptifkualitatif. Adapun sumber data dan instrumen yang digunakan dalam penelitian ini adalah observasi, wawancara dan studi dokumentasi. Berdasarkan penelitian yang telah dilakukan diperoleh hasil bahwa Sekolah Dasar Islam Terpadu Muhammadiyah Sinar Fajar Cawas dan Sekolah Dasar Muhammadiyah Program Khusus Bayat telah menerapkan kurikulum 2013. Sehingga guru memiliki peranan yang sangat penting dalam pendidikan. Di antara peranan guru yang ditunjukkan di kedua sekolah tersebut adalah guru sebagai perencana, pengelola, pelaksana dan evaluator. Selain itu, guru juga berperan sebagai pentransfer ilmu, pembina akhlak mulia, mediator dan fasilitator. Dalam penerapan strategi pembelajaran pendidikan agama Islam dengan media powerpoint di kedua sekolah tersebut mampu memberikan motivasi dan meningkatkan semangat belajar peserta didik serta prestasibelajarnya. Dalam pemanfaatan strategitersebut mampu menjadikan proses pembelajaran semakin lebih menarik, efektif, efisien dan dapat membantu dalam pengkondisian peserta didik dalam proses pembelajaran serta menambah rasa percaya diribagi guru pendidikan agama Islam. Adapun untuk materi yang disampaikan dengan memanfaatkan strategi ini, maka lebih mudah dipahami dan penyimpanan filenya lebih praktis. Faktor pendukung dalam penerapan strategi pembelajaran pendidikan agama Islam dengan media powerpoint di Sekolah Dasar Islam Terpadu Muhammadiyah Sinar Fajar Cawas dan Sekolah Dasar Muhammadiyah Program Khusus Bayat adalah kemampuan guru dalam mengoperasikan komputer, ketersediaan sumber media, sarana dan prasarana berbasis komputer di sekolah, dukungan dari kepala sekolah, dan kondisi lingkungan sekolah yang kondusif serta budaya saling tolong menolong yang terbangun cukup kuat. Adapun untuk faktor penghambatnya adalah kurang terbiasanya guru dalam menggunakan media powerpoint dalam proses pembelajaran, waktu persiapan yang masih terbatas, dan jumlah sarana dan prasarana berbasis komputer yang masih terbatas juga.

Kata Kunci: strategi pembelajaran; media; powerpoint.

\section{PENDAHULUAN}

Pendidikan memiliki peranan penting dalam kehidupan manusia, karena pendidikan merupakan suatu sarana untuk membangun martabat dan peradaban manusia sebagai seorang individu sekaligus merupakan bagian dari suatu komunitas. Selain itu, pendidikan juga diyakini memiliki kemampuan untuk membawa pesan-pesan universal yang dapat menjawab berbagai persoalan dalam kehidupan. Melalui pendidikan setiap individu berproses dan berpotensi menjadi manusia yang memiliki kualitas baik secara mental, spiritual maupun pengetahuan. ${ }^{1}$ Sehingga dalam menentukan arah perkembangan,

1 Heri Widodo, Potret Pendidikan di Indonesia dan Kesiapannya Dalam Menghadapi Masyarakat Ekonomi Asia (MEA), dalam Cendikia, Jurnal Pendidikan Islam, Vol. 13, No. 2, 2015, hlm. 300. kemajuan dan peradaban suatu bangsa tidak bisa terpisahkan dari proses pendidikan yang dilakukan. Maka dari itu, pendidikan adalah salah satu kebutuhan pokok bagi setiap manusia dan bahkan umat yang harus terpenuhi. ${ }^{2}$

Pendidikan secara disadari maupun tidak adalah awal dari sebuah peletakan dasar-dasar nilai peradaban dan kebudayaan di dunia ini. Suatu proses yang diharapkan dalam usaha pendidikan ini adalah suatu proses yang terarah dan memiliki tujuan yang jelas, yakni mengarahkan anak didik kepada titik optimal kemampuannya. ${ }^{3}$ Itulah hakekat

2 Muthoifin, Pemikiran Pendidikan Multikultural Ki Hadjar Dewantara, dalam Jurnal Intizar, Vol. 21, No. 2, 2015, hlm. 299.

3 Aminatul Zahroh, Membangun Kualitas Pembelajaran Melalui Dimensi Profesionalisme Guru, (Bandung: Yrama Wadya, 2015), hlm.1. 
dari tujuan pendidikan, yaitu membentuk individu menjadi seorang yang berkualitas. ${ }^{4}$ Hal ini sesuai dengan visi pendidikan nasional yaitu mewujudkan sistem pendidikan sebagai pranata sosial yang kuat dan berwibawa utuk memberdayakan semua warga negara Indonesia agar berkembang menjadi manusia yang berkualitas sehingga mampu dan proaktif menjawab tantangan zaman yang selalu berubah. Terkait dengan visi pendidikan nasional tersebut, reformasi pendidikan di antaranya mengenai pergeseran paradigma proses pendidikan, dari paradigma pengajaran ke paradigma pembelajaran. Paradigma pengajaran yang lebih menitikberatkan peran pendidik dalam mentransformasi pengetahuan kepada peserta didiknya bergeser kepada paradigma pembelajaran yang memberikan peran lebih banyak kepada peserta didik untuk mengembangkan potensi dan kreatifitas dirinya dalam rangka membentuk manusia yang memiliki kekuatan spiritual keagamaan, berakhlak mulia, berkepribadian, memiliki kecerdasan dan estetika, sehat jasmani dan rohani serta ketrampilan yang dibutuhkan bagi dirinya, masyarakat, bangsa dan negara. ${ }^{5}$

Lembaga pendidikan saat ini tidak hanya dituntut harus mengantarkan peserta didik lulus dengan nilai tinggi, tetapi juga harus mampu mengantarkan peserta didik memiliki peluang mendapat sekolah favorit, juara olimpiade, maupun mempunyai peluang meraih jurusan terbaik pada perguruan tinggi termashur. ${ }^{6}$ Sehingga

4 M. Djumransjah, Dimensi-Dimensi Filsafat Pendidikan Islam, (Malang: Kutub Minar, 2005), hlm.12.

5 Penjelasan Atas Peraturan Pemerintah Republik Indonesia Nomor 19 Tahun 2005 Tentang Standar Nasional Pendidikan., https://www.unm.ac.id/files/ surat/pp-19-tahun-2005-ttg-snp.pdf (diakses pada 5 Agustus 2019 pukul 10.10).

6 Eko Supriyanto, Pemenuhan Kebutuhan Stakeholder Melalui Pendesainan Kurikulum Madrasah Berbasis SKS, dalam Edukasi, Jurnal Penelitian dan Artikel Pendidikan, Vol. 9, No. 2, 2017, hlm. 36. lembaga pendidikan juga terus berusaha menyesuaikan dengan perkembangan peserta didik, menyelenggarakan proses pembelajaran yang inovatif, menarik dan efektif, penggunaan media pembelajaran yang berbasis teknologi, dilengkapi dengan sarana dan prasarana yang mendukung tujuan pembelajaran, serta melakukan evaluasi di setiap akhir proses pembelajaran guna mengukur sejauh mana tingkat kemampuan peserta didik sebagai standarisasi pendidikan nasional.

Dalam kenyataannya pendidikan nasional di Indonesia menghadapi berbagai permasalahan dan tantangan yang sangat kompleks. Mulai dari indeks pembangunan pendidikan untuk semua atau education for all (EFA) yang kian menurun setiap tahunnya, adanya jurang yang lebar antara tujuan ideal dengan realitas lapangan, sistem pendidikan yang masih bersifat parsial, tidak utuh dan tidak sistematis hingga out put yang memiliki karakteristik yang terpecah. Selain itu juga adanya kurikulum yang dianggap kurang mencerdaskan dan kurang progresif, karena rumusannya hanya mampu menjawab persoalan dalam jangka waktu 5 atau 10 tahun ke depan dan nalar egoisme kedua orang tua yang memaksa anaknya untuk belajar suatu pelajaran tertentu atau masuk sekolah tertentu yang tidak diminati oleh anak dan masih banyak lagi. ${ }^{7}$ Bahkan adanya ketidakpuasan stakeholder atas desain kurikulum dan hasil pendidikan yang terlalu condong pada aspek kognitif yang mengesampingkan aspek afektif. ${ }^{8}$

Berikutnya adalah terkait proses pembelajaran yang masih lemah, dorongan guru kepada peserta didik dalam mengembangkan kemampuan berpikir masih sangat kurang. Proses

7 Asnil Aidah Ritonga dan Muhammad Basri, Potret Buram Pendidikan Nasional, dalam, Tazkiya, Jurnal Pendidikan Islam, Vol. V, No. 1, 2016, hlm. 54.

8 Eko Supriyanto, Pemenuhan Kebutuhan Stakeholder Melalui Pendesainan Kurikulum Madrasah Berbasis SKS, hlm. 37. 
pembelajaran di kelas seringkali masih diarahkan kepada kemampuan untuk menghafal informasi; otak dipaksa untuk mengingat dan menimbun berbagai informasi tanpa dituntut dan diarahkan untuk memahami informasi yang diingat supaya menghubungkannya dengan kehidupan sehari-hari. Sehingga mengakibatkan ketika peserta didik lulus dari sekolah, mereka hanya pintar secara teori, tapi miskin dan lemah aplikasi.

Kenyataan ini berlaku hampir semua mata pelajaran, termasuk mata pelajaran pendidikan agama Islam, dimana peserta didik tidak mampu mengembangkan kemampuannya untuk berpikir kritis dan sistematis, tidak dapat mengembangkan sikap yang sesuai dengan norma-norma agama, karena proses pembelajaran hanya dituntut dan diarahkan agar peserta didik bisa menguasai dan menghafal materi pelajaran saja. Pendidikan di sekolah tidak diarahkan untuk membangun dan mengembangkan karakter serta potensi yang dimiliki.; dengan kata lain proses pendidikan tidak diarahkan membentuk manusia yang cerdas, memiliki kemampuan memecahkan masalah hidup, serta tidak diarahkan untuk membentuk manusia yang kreatif dan inovatif. ${ }^{9}$ Padahal, pendidikan agama Islam berupaya untuk memelihara dan mengembangkan fitrah manusia guna merealisasikan terwujudnya manusia muslim yang beriman dan bertakwa serta berilmu pengetahuan yang mampu mengabdikan dirinya kepada Allah dengan sikap dan kepribadian utuh yang menunjukkan kepada penyerahan diri kepada Allah dalam segala aspek kehidupan dunia dan akhirat. ${ }^{10}$

\footnotetext{
9 Wina Sanjaya, Strategi Pembelajaran Berorientasi Standar Proses Pendidikan, (Jakarta: Kencana Prenada Media Group, 2010), hlm.1-2.

10 Muthoifin, Sistem Pendidikan Nasional dan Pendidikan Islam: Studi Kritis Pemikiran Ki Hadjar Dewantara Perspektif Islam, dalam Jurnal Wahana Akademika, Vol. 2, No. 1, 2015, hlm. 69-72.
}

Dalam upaya peningkatan kualitas pendidikan, standar proses pendidikan memiliki peranan yang sangat penting. Oleh sebab itu, seideal apapun standar isi dan standar lulusan maupun standar yang lain, jika tidak didukung oleh standar proses yang baik dan memadai maka standar-standar tersebut tidak akan berguna dan memiliki nilai.

Dalam implementasi standar proses pendidikan, guru merupakan komponen terpenting, sebab keberhasilan pelaksanaan proses pendidikan sangat tergantung pada guru sebagai pelaksananya. Oleh sebab itulah maka upaya peningkatan kualitas pendidikan harus dimulai dari pembenahan kemampuan guru, khususnya guru pendidikan agama Islam. Dan salah satu kemampuan yang harus dimiliki oleh guru pendidikan agama Islam adalah bagaimana merancang suatu strategi pembelajaran yang sesuai dengan tujuan dan kompetensi yang akan dicapai. Sehingga harus mempersiapkan strategi pembelajaran yang variatif dan inovatif, karena secara realita tidak semua tujuan bisa dicapai hanya dengan satu strategi saja. ${ }^{11}$

Untuk itu, dalam penelitian ini penulis lebih memfokuskan pembahasan tentang strategi pembelajaran. Penulis menilai bahwa strategi pembelajaran merupakan perihal yang perlu diketahui oleh guru, agar dipelajari, dipahami dan dipraktekkannya. Dan juga guru harus memiliki strategi pembelajaran yang lebih kreatif dan inovatif lagi serta tepat dan terukur dalam proses pembelajaran setiap lembaga pendidikan, khususnya lembaga pendidikan Muhammadiyah dengan memanfaatkan berbagai media yang ada dan tersedia. Strategi pembelajaran tersebut dihubungkan dengan pelajaran pendidikan agama Islam, dengan pengertian bahwa fokus penelitian tesis ini akan mengungkap

\footnotetext{
11 Wina Sanjaya, Strategi Pembelajaran, hlm.xiv.
} 
strategi pembelajaran yang digunakan guru pendidikan agama Islam dalam menyampaikan materi ajarnya.

Sekolah Dasar Islam Terpadu Muhammadiyah Sinar Fajar Cawas dan Sekolah Dasar Muhammadiyah Program Khusus Bayat Kabupaten Klaten, menjadi pilihan penulis untuk dijadikan obyek penelitian karena kedua sekolah tersebut dalam melakukan proses pembelajaran telah menerapkan active learning, sehingga kelas menjadifleksibeldan tidak kaku serta pembelajaran yang dilakukan berbasis multimedia dan komputer, sehingga dalam proses pembelajaran lebih variatif, inovatif, kreatif dan menyenangkan.

Dari latar belakang di atas, maka penulis melakukan penelitian tesis yang berjudul " Strategi Pembelajaran Inovatif Pendidikan Agama Islam Dengan Media PowerPoint Dalam Meningkatkan Mutu Pendidikan di Sekolah Dasar Islam Terpadu Muhammadiyah Sinar Fajar Cawas dan Sekolah Dasar Muhammadiyah Program Khusus Bayat Kabupaten Klaten Tahun 2019."

\section{METODE PENELITIAN}

Jenis penelitian ini menggunakan jenis penelitian lapangan (field research), yakni penelitian yang diadakan secara langsung dengan objek penelitian dan dilakukan suatu pengumpulan data yang berada di lapangan. Penelitian ini termasuk pendekatan kualitatif, yakni pendekatan penelitian yang mengungkap situasi sosial tertentu dengan mendeskripsikan kenyataan secara benar, dibentuk oleh kata-kata berdasarkan teknik pengumpulan dan analisis data yang relevan yang diperoleh dari situasi yang alamiah. Dengan pendekatan tersebut peneliti akan mendeskripsikan kenyataan secara benar berdasarkan analisis data yang diperoleh. ${ }^{12}$ Analisis data dalam penelitian

12 Djam'an Satori dan Aan Komariah, Metode Penelitian Kualitatif, (Bandung: Alfabeta, 2009), hlm.23. kualitatif dilakukan sejak peneliti menyusun proposal, melaksanakan pengumpulan data di lapangan sampai peneliti mendapatkan seluruh data. ${ }^{13}$ Dengan penelitian kualitatif deskriptif ini, peneliti berusaha mengungkap strategi pembelajaran pendidikan agama Islam dengan media powerpoint di Sekolah Dasar Islam Terpadu Muhammadiyah Sinar Fajar Cawas dan Sekolah Dasar Muhammadiyah Program Khusus Bayat kabupaten Klaten sebagaimana adanya yang terjadi di lapangan, serta berusaha menghindarkan dari pandangan subyektifitas peneliti. Adapun data yang diteliti dan dilaporkan dalam tesis ini adalah hasil observasi, wawancara, dan dokumentasi.

Subyek dan Obyek Penelitian. Dalam penelitian ini yang menjadi subyek dan obyek penelitian adalah kepala sekolah SDIT Muhammadiyah Sinar Fajar Cawas dan SD Muhammadiyah Program Khusus Bayat, wakil kepala bagian kurikulum, guru pendidikan agama Islam, kepala TU dan melibatkan pihak lain yang diperlukan.

\section{Metode Pengumpulan Data:}

Observasi. Yaitu pengamatan langsung untuk memperoleh gambaran yang jelas tentang objek penelitian, penulis mengadakan pengamatan secara langsung terhadap objek penelitian itu. Adapun yang akan menjadi sasaran dalam observasi adalah lingkungan sekolah termasuk di dalamnya antara lain sarana ibadah, perpustakaan, kebersihan serta aktivitas di sekolah yang berhubungan dengan strategi pembelajaran pendidikan agama Islam di SDIT Muhammadiyah Sinar Fajar Cawas dan SD Muhammadiyah Program Khusus Bayat.

Wawancara. Wawancara adalah percakapan dengan maksud tertentu. Percakapan itu dilakukan oleh dua

13 Sugiyono, Memahami Penelitian Kualitatif, (Bandung: Alfabeta, 2009), hlm.3. 
pihak, yaitu pewawancara (interviewer) yang mengajukan pertanyaan dan terwawancara (interview) yang memberikan jawaban atas pertanyaan itu. ${ }^{14}$ Dalam penelitian ini menggunakan metode wawancara terstruktur. Wawancara ini dilakukan oleh peneliti dengan cara terlebih dahulu mempersiapkan bahan pertanyaan yang akan diajukan dalam wawancara nanti. ${ }^{15}$ Metode tersebut digunakan untuk mendapatkan data-data yan sifatnya penjelasan lebih lanjut dari data yang didapat dari hasil observasi, maupun data-data yang belum tercakup dari hasil observasi maupun dokumentasi.

\section{Dokumentasi}

Dokumen bisa berbentuk tulisan, gambar, atau karya-karya monumental dari seseorang. ${ }^{16}$ Sebagian penelitian bahkan hanya mengandalkan (kombinasi) dokumen-dokumen ini, tanpa dilengkapi dengan wawancara, bila data dalam dokumen-dokumen ini dianggap lengkap. ${ }^{17}$ Metode ini digunkan untuk mencari informasi terkait dengan gambaran umum SDIT Muhammadiyah Sinar FajarCawas danSD Muhammadiyah Program Khusus Bayat kabupaten Klaten seperti profil sekolah, letak geografis, visi misi, struktur organisasi, dan sebagainya yang tentunya menunjang penelitian

Metode Analisis Data

Analisis data dalam penelitian kualitatif dilakukan pada saat pengumpulan data berlangsung, dan setelah selesai pengumpulan data dalam periode tertentu. Analisis data dilakukan secara interaktif dan terus menerus sampai tuntas sehingga diperoleh

14 Lexy J. Moleong, Metodologi Peneletian Kualitatif. (Bandung: Rosda, 2010) hlm.186.

15 Muhammad Idrus, Metode Penelitian Ilmu Sosial, hlm. 107

16 Sugiyono, Memahami Penelitian Kualitatif, hlm.240.

17 Deddy Mulyana, Metodologi Penelitian Kualitatif Paradigma Baru Ilmu Komunikasi dan Ilmu Sosial Lainnya, (Bandung: Rosda, 2003) hlm.195. data yang kredibel. ${ }^{18}$ Aktivitas dalam menganalisis data pada penelitian ini terdiri dari empat komponen yang inheren, yaitu pengumpulan data, reduksi data, penyajian data serta verifikasi atau penarikan kesimpulan.

\section{HASIL DAN PEMBAHASAN \\ Pelaksanaan Kurikulum dan Peranan Guru di SDIT Muhammadiyah Sinar Fajar Cawas dan SD Muhammadiyah Program Khusus Bayat}

Dalam pelaksanaan kurikulum pembelajaran di SDIT Muhammadiyah Sinar Fajar Cawas danSD Muhammadiyah Program Khusus Bayat telah menerapkan kurikulum 2013. Sehingga para guru lebih banyak berperan sebagai fasilitator. Selain itu, guru di kedua sekolah tersebut juga memiliki peran sebagai perencana, pembelajaran, pelaksana dan pengelola juga evaluator dalam pembelajaran. Bahkan, guru di kedua sekolah tersebut juga berperan sebagai pentransfer ilmu pengetahuan, memberikan pembinaan dan pengarahan akhlak mulia, mediator dalam menyelesaikan berbagai permasalahan perkembangan peserta didik. Hal ini sejalan dengan teori yang diungkapkan oleh Gage dan Berliner bahwa peran utama guru dalam pembelajaran adalah sebagai planner, organizer dan evaluator. ${ }^{19}$ Dan teori yang disampaikan oleh Dr. Rusman, M.Pd. bahwa peran dominan guru adalah sebagai demonstrator, pengelola kelas, mediator, fasilitator serta sebagai evaluator. ${ }^{20}$

18 Muhammad Idrus, Metode Penelitian Ilmu Sosial, hlm. 145 .

19 Suyono dan Hariyanto, Belajar dan Pembelajaran Teori dan Konsep Dasar, (Bandung: PT. Remaja Rosdakarya, 2014), hlm. 187.

20 Askhabul Kirom, Peran Guru dan Peserta Didik Dalam Proses Pembelajaran Berbasis Multikultural, Dalam Al Murabbi, Jurnal Pendidikan Islam, Vol. 3, No. 1, 2017, hlm. 73-74. 
Pemanfaatan Strategi Pembelajaran Inovatif Dengan Media PowerPoint di SDIT Muhammadiyah Sinar Fajar Cawas dan SD Muhammadiyah Program Khusus Bayat

Gurniman Sutarmo menyatakan bahwa media powerpoint merupakan salah satu media yang digunakan dalam efektifitas pembelajaran pendidikan agama Islam yang mempunyai banyak kelebihan, di antaranya (1) dapat menyajikan teks, gambar, film, sound efek, musik, grafik dan animasi, (2) mempunyai daya tarik sehingga mampu menimbulkan ketertarikan atau minat, (3) penyajiannya bersifat poin-poin yang mampu menimbulkan ingatan dan pengertian yang kuat, (4) efisien, mudah direvisi dan disimpan, (5) dapat diulang sesuai dengan kebutuhan, (6) bisa diperbanyak dalam waktu singkat, (7) hemat biaya, (8) dapat digunakan berkali-kali di tempat yang berbeda. ${ }^{21}$ Selain itu, Nurhidayati juga menyatakan bahwa keunggulan penggunaan media powerpoint adalah lebih praktis, variatif, menarik dan tidak membosankan, mampu menyajikan berbagai kombinasi dan dapat digunakan secara berulangulang. ${ }^{22}$

Pemanfaatan media powerpoint dalam strategi pembelajaran pendidikan agama Islam di SDIT Muhammadiyah Sinar Fajar Cawas danSD Muhammadiyah Program Khusus Bayat mampu mengatasi kejenuhan peserta didik dalam proses pembelajaran dan bahkan bisa memberikan motivasi bagi peserta didik dalam mengikuti pembelajaran.

Menurut Ustadz Maryadi, selaku guru PAI di SDIT Muhammadiyah

21 Gurniman Sutarno, Efektivitas Pembelajaran PAI Menggunakan Media Power Point Dengan Video Muhasabah Di Kelas 5 SDIT Iqra' 1 Kota Bengkulu, dalam al-Bahtsu, Jurnal Pendidikan Islam, Vol. 3, No. 2, 2018, hlm. 183.

22 Nurhidayati, Media Powerpoint dan Pemanfaatannya Dalam Proses Pembelajaran Bahasa Arab, dalam Prosiding Konferensi Nasional Bahasa Arab V di Malang, 5 Oktober 2019, hlm. 464.
Sinar Fajar Cawas menyatakan bahwa pemanfaatan media powerpoint dalam strategi pembelajaran dapat menjadikan:

1) Pembelajaran lebih efektif dan efisien.

2) Pembelajaran menjadi lebih hidup dan bervariasi.

3) Lebih mudah dalam mengatur dan mengkondisikan peserta didik.

4) Terasa lebih ringan dan menyenangkan dalam melaksanakan proses pembelajaran.

5) Media bantu para peserta didik dalam memahami materi pembelajaran, sehingga mampu meningkatkan hasil prestasi belajar. Hal ini terlihat dari hasil pencapaian nilai rata-rata kelas VI sebelum penggunaan strategi pembelajaran dengan media powerpoint dan sesudahnya menunjukkan bahwa sebelum menggunanakan strategi pembelajaran dengan media powerpoint nilai rata-rata kelas VI materi "Ayo Membayar Zakat" adalah 72, 845 dan setelah menggunakan strategi pembelajaran dengan media powerpoint nilai rata-rata kelas meningkat menjadi $83,94 .{ }^{23}$

Pernyataan serupa juga diungkapkan oleh Bapak Gilang, selaku guru PAI di SD Muhammadiyah Program Khusus Bayat bahwa:

"Pembelajaran dengan menggunakan strategi berbasis powerpoint bisa dikatakan lebih menyenangkan dan banyak keuntungannya. Di antara keuntungan dari penerapan strategi pembelajaran berbasis powerpoint adalah lebih efektif dan efisien dalam waktu, energi dan pikiran, tampilannya lebih menarik, variatif dan menyenangkan, anak-anak bisa lebih termotivasi dan fokus kembali

23 Dokumentasi dan hasil wawancara dengan Maryadi, S.Pd., (Guru Pendidikan Agama Islam di SDIT Muhammadiyah Sinar Fajar Cawas) pada tanggal 7 Nopember 2019. 
dalam mengikuti pembelajaran di kelas, bahkan anak bisa melihat secara langsung dan seakan terlihat nyata tentang gambaran materi melalui gambar animasi atau video yang telah disiapkan dalam file powerpoint, cara penyampaiannya lebih praktis dan langsung pada point intinya, penyimpanannya lebih mudah dan tidak membutuhkan banyak ruang, filenya bisa tersimpan tahan lama dan bisa dimanfaatkan oleh siapa saja, serta bisa lebih meminimalkan jumlah jam tatap muka, yaitu materi yang biasanya harus disampaikan 6 kali pertemuan bisa dipadatkan jadi 4 kali pertemuan dan bagi anak yang sekiranya berhalangan hadir untuk mengikuti pembelajaran atau saat mendekati ujian file bisa dikirim melalui media whatsapp baik secara pribadi maupun group agar anak belajar mandiri." 24

Bapak Gilang juga menyampaikan pengalamannya saat mengajar di kelas menggunakan strategi pembelajaran dengan media powerpoint ternyata mampu meningkatkan hasil prestasi nilai akademik peserta didik. Hal ini beliau buktikan dengan data nilai ratarata ulangan harian pembelajaran PAI sebagaimana berikut: ${ }^{25}$

\section{Pelaksanaan Strategi Pembelajaran Inovatif Pendidikan Agama Islam Dengan Media PowerPoint di SDIT Muhammadiyah Sinar Fajar Cawas dan SD Muhammadiyah Program Khusus Bayat}

a. Dimulai dengan guru mengidentifikasi program, hal ini dilakukan untuk melihat kesesuaian

24 Wawancara dengan Gilang Rizqi Ridha R, selaku guru Pendidikan Agama Islam di SD Muhammadiyah Program Khusus Bayat pada tanggal 11 Nopember 2019.

25 Dokumentasi sekolah dikutip pada tanggal 12 Nopember 2019. antara program yang dibuat dengan materi yang akan disampaikan dan peserta didik yang menjadi sasarannya.

b. Guru mempersiapkan dan mengumpulkan bahan pendukung sesuai dengan kebutuhan materi dan peserta didik yang menjadi sasarannya, seperti gambar, animasi, video, dan suara. Bersamaan dengan hal tersebut, guru juga melakukan penyusunan materi yang diambil dari bahan utama dengan mengemas penyusunanya menjadi uraian pendek atau pokok-pokok (poin) pembahasan.

c. Setelah bahan terkumpul dan materi pokok telah terangkum, selanjutnya adalah proses pengerjaan powerpoint sampai selesai. Selanjutnya dapat mengubah hasil akhir presentasi dalam bentuk slide show, web pages atau executable file.

d. Setelah program presentasi selesai dibuat dan sebelum digunakan untuk pembelajaran, terlebih dahulu dilakukan review program dari segi bahasa, teks, tata letak, dan ketepatan konsep, lalu direvisi dan selanjutnya program powerpoint siap digunakan dan ditampilkan melalui laptop dengan menghubungkannya ke LCD proyektor.

e. Selanjutnya guru membuka pembelajaran yang diawali dengan kegiatan pendahuluan atau apersepsi sekaligus memberikan motivasi.

f. Kemudian guru menjelaskan tujuan pembelajaran dan kompetensi yang hendak dicapai.

g. Masuk ke inti, yakni guru menampilkan slide demi slide materi pembelajaran dengan media powerpoint yang telah dipersiapkan.

h. Dan di sela-sela pembelajaran guru juga mempersilahkan para peserta didik untuk memberikan komentar atau menyampaikan gagasannya 
agar suasana pembelajaran menjadi hidup.

i. Selanjutnya guru melakukan evaluasi dengan memberikan soal dari materi yang telah disampaikan.

j. Rencana tindak lanjut dan penutupan. ${ }^{26}$

Berikutiniskema penyampaianmateri pembelajaran dengan menggunakan strategi pembelajaran berbasis media powerpoint

\section{Dampak Penggunaan Strategi} Pembelajaran Inovatif Pendidikan Agama Islam Dengan Media PowerPoint Bagi Guru dan Peserta Didik

Strategi pembelajaran pendidikan agama Islam dengan media powerpoint memiliki dampak positif bagi guru, yaitu menambah rasa percaya diri pada guru dalam menyampaikan materi pembelajaran, meringankan beban tugas mengajar, semakin diterima oleh peserta didik, penyampaian materi bisa lebih runtut dan terarah serta proses pembelajaran semakin lebih menarik dan hidup sehingga hasilnya bisa lebih optimal.

Adapun dampak posistif bagi peserta didik adalah mampu memberikan motivasi dan semangat peserta didik mengikuti proses pembelajaran, menambah daya fokus, mempermudah peserta didik dalam memahami materi pembelajaran serta meminimalkan rasa kejenuhan saat proses pembelajaran.

\section{Faktor Pendukung dan Penghambat Pelaksanaan Strategi Pembelajaran Inovatif Pendidikan Agama Islam Dengan Media PowerPoint}

Dalam pelaksanaan strategi pembelajaran pendidikan agama Islam dengan media powerpoint di SDIT

26 Observasi di SDIT Muhammadiyah Sinar Fajar Cawas pada tanggal 11 Nopember 2019 dan di SD Muhammadiyah Program Khusus Bayat pada tanggal 12 Nopember 2019.
Muhammadiyah Sinar Fajar Cawas dan SD Muhammadiyah Program Khsusus Bayat ada faktor-faktor yang mendukung, yaitu (1) adanya kemampuan yang dimiliki oleh para guru pendidikan agama Islam dalam menggunakan media berbasis komputer dalam suatu pembelajaran; (2) ketersediaan media maupun alat, baik berupa LCD maupun laptop yang siap untuk dimanfaatkan; (3) dukungan dari kepala sekolah yang telah memberikan kewenangan kepada para guru untuk melakukan inovasi, kreasi dan mengekspresikan kemampuannya dalam menerapkan dan mengembangkan strategi pembelajaran baik di kelas maupun di luar kelas selama sesuai dengan kode etik dan visi misi sekolah; serta (4) lingkungan sekolah yang kondusif dan budaya saling tolong menolong dalam mensukseskan program pembelajaran antar sesama guru di kedua sekolah tersebut.

Sedangkan faktor-faktor yang menghambat dalam penerapan strategi pembelajaran pendidikan agama Islam di kedua sekolah tersebut adalah:

(1) Tidak semua guru pendidikan agama Islam memahami dan menguasai program powerpoint serta terbiasa menggunakannya.

(2) Keterbatasan waktu dalam mempersiapkan alat, media dan materi dengan media powerpoint.

(3) Ketersediaan LCD proyektor di sekolah masih terbatas dan belum terpasang di setiap kelas, sehingga pemanfaatannya dalam proses pembelajaran harus bergiliran atau menunggu kelas lain yang kosong dan tidak digunakan untuk bergantian tempat pembelajaran. ${ }^{27}$

\section{PENUTUP}

Berdasarkan hasil penelitian dan analisis yang telah dilakukan, maka dapat disimpulkan sebagai berikut:

27 Dokumentasi sekolah dan observasi yang dilakukan pada 26 Oktober 2019. 
1. SDIT Muhammadiyah Sinar Fajar Cawas dan SD Muhammadiyah Program Khusus Bayat adalah sekolah yang mengiplementasikan kurikulum 2013. Kedua sekolah ini telah menunjukkan bahwa guru memiliki peranan yang sangat penting dalam proses pendidikan. Di antara peran guru yang ditunjukkan di kedua sekolah tersebut adalah guru sebagai perencana, pengelola, pelaksana dan evaluator dalam proses pendidikan. Selain itu, guru juga memiliki peran sebagai pentransfer ilmu pengetahuan, pembina akhlak mulia, mediator dan fasilitator. Adapun peran guru sebagai fasilitator terbilang masih belum maksimal karena dalam proses pembelajaran guru masih mendominasi setiap kegiatan pembelajaran.

2. Dalam penerapan strategi pembelajaran pendidikan agama Islam dengan media powerpoint di SDIT Muhammadiyah Sinar Fajar Cawas dan SD Muhammadiyah Program Khusus Bayat ternyata mampu memberikan motivasi dan meningkatkan semangat dan prestasi peserta didik dalam belajar. Begitu pula dalam pemanfaatannya mampu menjadikan proses pembelajarannya semakin lebih menarik dan diminati peserta didik, berjalan lebih efekif dan efisien, dapat membantu dalam pengkondisian peserta didik, lebih praktis penyimpanannya dan mudah dipahami, dan mampu menambah rasa percaya diribagiguru pendidikan agama Islam dalam mengajar. Tetapi pemanfaatan strategi pembelajaran pendidikan adama Islam dengan media powerpoint di kedua sekolah tersebut belum optimal, karena kemampuan guru dalam mengoperasikan media powerpoint masih terbatas, jumlah alat dan waktu untuk mempersiapkan juga masih terbatas.

3. Faktor yang menjadi pendukung dalam penerapan strategi pembelajaran dengan media powerpoint di SDIT Muhammadiyah Sinar Fajar Cawas dan SD Muhammadiyah Program Khusus Bayat adalah kemampuan guru dalam mengoperasikan komputer menjadi modal utama, ketersediaan sarana dan prasarana berbasis komputer di sekolah, dukungan dari kepala sekolah kepada para guru dalam berkreasi dan berinovasi dalam mengembangkan materi dan strategi pembelajaran, serta kondisi lingkungan sekolah yang kondusif dan budaya untuk saling tolong menolong dalam mensukseskan setiap program sekolah yang telah terbangun cukup kuat. Adapun faktor yang menjadi penghambat dalam penerapan strategi pembelajaran pendidikan agama Islam dengan media powerpoint di kedua sekolah tersebut adalah kurang terbiasanya guru untuk menggunakan media powerpoint dalam proses pembelajaran, waktu persiapan yang masih terbatas serta terbatasnya jumlah sarana dan prasarana berbasis komputer, seperti LCD proyektor dan laptop.

\section{Saran dan Rekomendasi}

Berdasarkan hasil penelitian yang telah dilakukan, maka penulis dapat memberikan beberapa saran dan rekomendasi kepada guru pendidikan agama Islam di SDIT Muhammadiyah Sinar Fajar Cawas danSD Muhammadiyah Program Khusus Bayat agar:

1. Terus berusaha lebih inovatif dan variatif lagi dalam memilih dan menyusun strategi pembelajaran dengan terus memperhatikan perkembangan dan kondisi peserta didik serta perkembangan jaman 
dan teknologi terkini, agar dalam pelaksanaan pembelajaran bisa menarik perhatian dan mampu memberikan motivasi peserta didik dalam proses pembelajaran pendidikan agama Islam.

2. Dalam proses pembelajaran guru pendidikan agama Islam dapat meningkatkan pemanfaatan media, terutama media powerpoint guna meningkatkan motivasi dan prestasi belajar peserta didik.

3. Penerapan pembelajaran melalui strategi pembelajaran dengan media powerpoint pada mata pelajaran pendidikan agama Islam tidak hanya dilaksanakan sampai penelitian ini selesai, tapi terus berlanjut dan dilaksanakan secara kontinue sebagai salah satu alternatif dalam meningkatkan hasil belajar.

4. Lebih semangat dan kreatif lagi dalam mengoptimalkan pemanfaatan sumber media pembelajaran yang tersedia disekolah, khususnya sumber media yang berbasis komputer, termasuk pemanfaatan program powerpoint dan pengembangannya.

5. Guru pendidikan agama Islam mengikuti pelatihan tentang teknologi, informasi dan komunikasi supaya mampu memanfaatkannya dengan baik dalam proses pembelajaran bersama peserta didik.

Adapun saran dan rekomendasi penulis untuk pihak sekolah adalah agar terus meningkatkan mutu pendidikan melalui pemberian dukungan dan fasilitas bagi para guru guna meningkatkan kemampuan mengajarnya dengan mengadakan atau mengikutsertakannya dalam diklat maupun pelatihan pemanfaatan sumber media pembelajaran serta melengkapi jenis-jenis sarana dan prasarana yang menunjang untuk meningkatkan mutu pembelajaran.

\section{DAFTAR PUSTAKA}

Djam'an Satori dan Aan Komariah. 2009. Metode Penelitian Kualitatif. Bandung: Alfabeta. Djumransjah, M. 2005. Dimensi-Dimensi Filsafat Pendidikan Islam. Malang: Kutub Minar. Zahroh, Aminatul. 2015. Membangun Kualitas Pembelajaran Melalui Dimensi Profesionalisme Guru. Bandung: Yrama Wadya.

Idrus, Muhammad. 2009. Metode Penelitian Ilmu Sosial. Jakarta: Erlangga.

Sanjaya, Wina. 2010. Strategi Pembelajaran Berorientasi Standar Proses Pendidikan. Jakarta: Kencana Prenada Media Group.

Moleong, Lexy J. 2010. Metodologi Peneletian Kualitatif. Badung: Rosda.

Mulyana, Deddy. 2003. Metodologi Penelitian Kualitatif Paradigma Baru Ilmu Komunikasi dan Ilmu Sosial Lainnya. Bandung: Rosda.

Sugiyono. 2009. Memahami Penelitian Kualitatif. Bandung: Alfabeta.

Suyono dan Hariyanto. 2014. Belajar dan Pembelajaran Teori dan Konsep Dasar. Bandung: PT. Remaja Rosdakarya.

Asnil Aidah Ritonga dan Muhammad Basri. 2016. Potret Buram Pendidikan Nasional, dalam, Tazkiya, Jurnal Pendidikan Islam, Vol. V, No. 1:. 54.

Kirom, Askhabul. 2017. Peran Guru dan Peserta Didik Dalam Proses Pembelajaran Berbasis Multikultural, dalam Al Murabbi, Jurnal Pendidikan Islam, Vol. 3, No. 1: 72. 
PROFETIKA, Jurnal Studi Islam, Vol.21, No. 1, Special Issue 2020: 109-120

Muthoifin. 2015. Pemikiran Pendidikan Multikultural Ki Hadjar Dewantara, dalam Jurnal Intizar, Vol. 21, No. 2: 299.

Muthoifin. 2015. Sistem Pendidikan Nasional dan Pendidikan Islam: Studi Kritis Pemikiran Ki Hadjar Dewantara Perspektif Islam, dalam Jurnal Wahana Akademika, Vol. 2, No. 1: 69-72.

Supriyanto, Eko. 2017. Pemenuhan Kebutuhan Stakeholder Melalui Pendesainan Kurikulum Madrasah Berbasis SKS, dalam Edukasi, Jurnal Penelitian dan Artikel Pendidikan, Vol. 9, No. 2: 35-46.

Sutarno, Gurniman. 2018. Efektivitas Pembelajaran PAI Menggunakan Media Power Point Dengan Video Muhasabah Di Kelas 5 SDIT Iqra' 1 Kota Bengkulu, dalam al-Bahtsu, Jurnal Pendidikan Islam, Vol. 3, No. 2: 183.

Widodo, Heri. 2015. Potret Pendidikan di Indonesia dan Kesiapannya Dalam Menghadapi Masyarakat Ekonomi Asia (MEA). dalam Cendikia, Jurnal Pendidikan Islam, Vol. 13, No. 2: 300.

Penjelasan Atas Peraturan Pemerintah Republik Indonesia Nomor 19 Tahun 2005 Tentang Standar Nasional Pendidikan., https://www.unm.ac.id/files/surat/pp19-tahun-2005-ttg-snp.pdf (diakses pada 5 Agustus 2019 pukul 10.10).

Nurhidayati. 2019. Media Powerpoint dan Pemanfaatannya Dalam Proses Pembelajaran Bahasa Arab. Makalah disajikan dalam Prosiding Konferensi Nasional Bahasa Arab V di Malang, Malang, 5 Oktober. 